\title{
HISTORY OF THE CONGREGATIONAL CHURCH, OF DUBUQUE.
}

\section{A DISCOURBE DELIVERED ON SABBATH, APRIL 8, 1860, BY REV. JOHN O. HOLBROOK, PASTOR.}

Gratitude is not only bec sming but delightful-a source of pure, nnalloyed joy. In its exercise

"O'er the soul a pleasure steals

Sweet as the gentle breath of even

Making the bosom that it fills

A little heaven."

We spend far too little time in the review of God's dealings with us, and in recalling to mind with thankful hearts His kindness. Let us to-day look back on the way in which he has led us as a church, and see how appropriate on our lips are the words of the text.

As originally employed they had reference to the deliverance of the Israelites from captivity and their remarkable-restoration to their own land, where they were not only permitted to rebuild their sacred Temple, but were assisted in the work by their oppressors. And so wonderful was that whole transaction and the conduct of Cyrus towards them, unaccountable on any principal of worldly policy, that even the pagans confessed the hand of Jehovah in it. "Then said they among the heathen, The Lord hath done great things for them," to which the people of God replied, "The Lord hath done great thing for us; whereof we are glad." They acknowledged the greatness of the deliverance, and of the accompanying blessings, and gave God the glory, and then in the exuberance of their joy and gratitude exclaimed: "When the Lord turned the captivity of Zion we were like them that dream. Then was our mouth filled with laughter and our tongue with singing."

How exactly does this describe our feelings and circumstances as a church to-day, as with our beautiful and commodious house of worship completed, we enter upon a new era in our history 
Wonderful, indeed, have been the Providential interpositions in our behalf in times past, so wondertul that even the ungodly are compelled ta say, "The Lord hath done great things for them," to which with humble, grateful hearts we respond, "The Lord hath done great things for us ; whereof we are glad."

It is now not quite twenty-one years since a little band of Christians, five men and fourteen women, associated themselres together here and formed the nuclens of this church. Two of them only remain connected with the church, and of these two only one is at present a resident in this city. It was indeed a "day of small things" when these individuals without a pastor, without a house of worship and relying on missionary aid to sustain the means of grace, here laid the foundations of a church that has at length grown to be one of the most important in the State. But from such insignificant beginnings have often been developed the mightiest results in the kingdom of God.

But before entering into details in respect to this particular church and congregation let us glance at some facts in the history of the city.

Less than thirty years ago the whole territory that now constitutes the State of Iowa, was in the possession of the native Indian tribes. The Sacs and Foxes roamedorer these prairies engaged in their savage purstits; their council-fires burned where now stand cities and villages of civilized men, and their idolatrous rites and ceremenies were practiced where now hundreds of christian claturches mect statedly for worship. Not a settlement of whites had then been established west of the Mississippi, within what are now the borders of this State.

Julien Dubuque, from whom our city derives its name, resided here from 1800 to 1810 , when he died, having intermarried with the Indians, and carried on lead mining and smelting operations, but he obtained no title to lands. His grave is on the brow of one of the lofty bluff's just below the city, overlooking the Mississippi. A few Americans, some of whom are now among our wealthy and prominent citizens, had also visited this locality for mining purposes in 1830 , but they were not allowed to prosecute the business, being driven off by the U.S. 
troops from Prairie du Chien, under Maj. Z. Taylor, commandant there, and afterwards President of the United States.

In the Antumn of 1832 a treaty was concluded between the agents of our General Government and the Indians, by which the latter ceded to the United States the narrow strip of territory called "The Black Hawk Purchase," lying immediately west of the Mississippi ; but the treaty was not ratified and possession given until June 1, 1833, not quite troenty-seven years ago, when the first legal settlement of the State by the whites began. Great anxiety was manifested to get access to the rich lead mines in this vicinity-which had been worked by individuals to some extent, for some time previously, with interruptions from U. S. troops-and great numbers of persons were encamped on the islands in front of this place and on the opposite shore in Illinois, waiting for the day to arrive when the territory should be opened and "claims" cuuld be made, and so great was the rush of immigrants that hundreds crossed the river within a few days, and the population gathered here numbered more than five hundred by October. The first settlers erected rude board "shanties" and log cabins for dwellings, and a few of the latter still stand. Thns was laid the foundation of a city that in ten years contained three thousand inhabitants, and now numbers over sixteen thousand, and is surpassed by few western towns in the substantial nature of its buildings and in its public improvements.

In such a population as was at tirst gathered here there was little of the religious element - almost no fear of God, in fact, or regard for man. A more loose and godless community than this is described to have been, conld scarcely be conceived of There was no recognition of the Sabbath as a day of sacred rest, and immorality in almost every form was openly and secretly practiced. Street fights, and murders, even, were not uncommon. A gentleman, now residing here, and one of our most respectable citizens, has informed me that he arrived in October, and in November, wishing to use a Bible, he searched the place thoroughly for one in vain, and was obliged to go to Galena to procure it. In 1834, several religions tamilies were added to the population and a weekly prayer-meeting 
was established. A Methodist circuit preacher, also, began that year to hold religious services once in four weeks in the place and the Rev. Mr. Kent, a missionary of the A. H. M. ' Society, stationed at Galena, preached here occasionally.

In the course of the year a $\log$ builaing was erected on what is now Washington Square, which for some time served the double purpose of a court-honse and meeting-house. Two ladies during this year established a Sabbath'School in a room over a grocery on Main street, where they taught about forty children, while all the stores and drinking and gambling saloons were open and business and amusements were prosecuted with even greater zest than on other days.

During this year (1834) a Methodist "class" was formed consisting of four members and this was the commencement of the first religious organization in the place. In 1842 the brick edifice, on the corner of Locust and Seventh strects, where the Centenary Methodist church worships, was completed and opened at a cost of about $\$ 3,000$. In 1835 a subscription paper was circulated among the citizens generally to raise the means for erecting a Roman Catholic church building, a priest* having been stationed here a little before. The corner stone was laid with considerable ceremony Aug. 15th, 1835 and the house completed at a cost of $\$ 5,000$, in 1836 . Last year it was pulled down, having become dilapidated and being superseded by the present spacions cathedral. Bishop Loras entered upon his duties here in 1838 , died in 1857 , and was succeeded by the present Bishop Smyth. There are now three very large Roman Catholic congregations in the city.

In the winter of 1835-'6, Rev. Cyrus Watson, a Presbyterian minister, preached here about three months, in the log building before referred to, alternating with the Methodists. At his instigation measures were taken for securing a house of worship, which resulted in the ereation of the "Stone Church," now occupied by the Campbellites, and where this congregation first worshipped, and in which I began my labors in this city. The corner stone was laid on the first day of Jnly, 1836. The fol-

*Father Samuel Muzzuchelli who died in Wisconsin in the winter of 1864. 
lowing extract from the Dubuque Visitor, of the 27 th of Julywhich paper was established in May of that year by Judge King, and was the first newspaper published in Iowa-gires an account of the ceremony :

"We had the pleasure of witnessing the highly-interesting ceremony of laying the corner-stone of the first Presbyterian church edifice in Wisconsin Territory (then) embracing the whole vast section west of Lake Michigan to the Missouri river, and north of the States of Illinois and Missouri. Three and a half years ago perhaps the smoke of an Indian wigwam rose from the very spot where this house is to be built. At that time the white man's dwelling was not to be found where our village now stands, nor in all the delightful country on our side of the great river. The ceremony lacked much of the pomp and circumstance which would have marked a similar occurence in older communities, but it was solemn and impressive. The corner stone was laid in the presence of Judge Dunn, Chief Justice of the Territory. At 4 o'clock P. Mr., a procession was formed and marched with music to the place selected for the church. A hymn was then sung and the throne of grace addressed in a fervent prayer by Mr. Benjamin Rupert, (in the absence of a minister), when a very eloquent and spirited address was delivered by Dr. T. Mason.* 'The corner stone was then laid, a memorandum of the most important events of the times, a copy of the Visitor, and the subscription for the church were deposited under it, and the ceremony closed with singing and prayer." No church organization was formed, however, until 1839.

Some idea of the state of morals in the place at this period may be formed from the following facts. An editorial in the Visitor of May 1st, says: "Another minister is wanted hereone who can reason, pray and sing, and enforce the fourth commandment." A correspondent of the New York Journal of Commerce writing trom this place about this time, said : "The principle amusement of the people seems to be playing cards Sundays and all. The law they carry in their pockets and are

*Judge King, Dr. Mason and Mr. Rupert are still living (1864) honored eitizens of the city they have helped to build. 
ready to read a chapter on the least provocation." But little influence from the Gospel had begun to be felt here, and the place had obtained a wide and unenviable notoriety, even though in the midst of a region by no means remarkable for its morality.

In 1839 this church was organized, as already said, of nineteen members, after the Presbyterian model, but which was changed subsequently by a nearly nnanimous vote to the Congregational ${ }^{2}$ form, atter the loss of the "Stone Church," and before the erection of another house of worship. In A pril, 1840, a Baptist 2 church was formed, and in the winter of 1841 they entered upon the occupancy of a small wooden building on Clay street, from which they removed to their present brick edifice on Main street in 1857. In 1844 a congregation of "Disciples," or followers of Alexander Campbell was gathered, who subsequently purchased the "Stone Church," where they now hold their services.

In 1838 a Protestant-Episcopal church was established, which afterwards became extinct, and was succeeded in March, 1845, by the present organization. The brick house of worship which they occupy was consecrated by Bishop Kemper in 1851 . About the jear 1847 or ' 48 the German Presbyterian church was gathered by Rev. P. Flenry from Switzerland.

In July 1850, the Congregational church having become quite large and containing a considerable number of Presbyterians, about twenty of its members were dismissed to form the First Presbyterian church, O. S. They erected a small brick structure for public worship on Main street, from which they removed to their present house on Locust street about two years since. In 1853 the Main Street Methodist church was formed for the oceupation of the fine brick edifice where they now worship.

In 1855 another colony left the Congregational church and laid the foundation of the Second Presbyterian church, N. S. At first they met in a public hall, then erected a small wooden house of worship on Ninth street from whence they removed to their present brick edifice on Locust street in 1858. A small associate Reformed Presbyterian church was organized in 1859 
which occupies the old Presbyterian church building on Ninth street. Besides these, there are in the city a German Methodist and a Lutheran church, and a Universalist Association, the latter meeting in Globe Hall.

But to return to our own church history. Being in this vicinity, I supplied the pulpit on the last Sabbath in Febrnary, 1842 , preaching in the "stone church," and on that received a unanimous "call" to become the pastor of the Congregational Church, which I accepted, entering upon my regular duties on the 20tl of March, eighteen years ago. On the 5th of April of the following year I was formally installed in office. When I began my labors the prospect was not by any means encouraging. The building where we met for worship was in an unfinished state, and was encumbered by a heavy debt with no means on hand or in prospect for liquidating it and completing the house. The number of members of the church by the record was 26 , but of these eight lived at a distance, and it was rare to see more than from three to five men and three or four women at the regular weekly prayer-meeting. The pastor began his work with some degree of fear, but with the hearty prayers and co-operation of the little church. We were obliged to "walk by faith and not by sight." $A$ good congregation was, however, soon gathered and additions were made to the church of seven on profession of faith and four by letter during the first year.

But the difficulty of sustaining and building up a church under such circumstances as we were placed in, can only be apprehended by one who has encountered it. The prevailing disregard of all religious restraints which characterizes ner settlements generally, and which was specially manitest here; the fact that many had emigrated hither for the express purpose in part of escaping from moral influences; the efforts of infidels and errorists to propagate their views, stimnlated to ten fold more vigor by the prospect of forestalling the truth and by the feebleness of the opposition of its friends; the rivalries and jealousies of different denominations each anxious to plant its own institutions in advance of all others, and the fact that those who were associated together in the church were 
comparatively strangers to each other and from different and far distant parts of our land and even from different countries, were few in number and limited in resources, and had everything to provide for their own and families' comfort, these all combined to retard the growth and prosperity of the enterprise.

We had members in our little church at the close of the first year, from no less than eighteen different States of the Union, and of seven different nations, all trained to different views and habits in some respects, accustomed to different styles of preaching and to various modes of managing church affairs, and measures for advancing the kingdom of Christ. They could not, therefore, act with the harmony and efficiency of a body all whose members had grown up together in the same community and under similar influences, nor could their be the same confidence in their leader and pastor. Besides this there was great fluctuation in the congregation and frequent changes in the membership of the church, and none of the stability which is seen in older communities. It was impossible for the minister to pour a steady flood of truth on the same minds for any considerable length of time, or to present the doctrines of the Gospel in a systematic and consecutive order to the attention of individuals. A terrible spirit of worldliness also prevaded the community and even invaded the church. All had come here to improve their pecuniary condition and some felt impelled by dire necessity to make business the first and great concern.

These were difficulties with which we had to contend in common with other churches, while there were some obstacles to our prosperity which were peculiar to us. In 1844 we were ejected from our house of worship under a mortgage given before my settlement and we were for a time obliged to worship in the Court House, and afterwards in the Baptist clurch which was vacant. But with some aid from abroad we succeeded at length in erecting a brick edifice, on a very eligible site on Main Street at a cost of about $\$ 3,000$. This subsequently became too small for our accomodation in consequence of a powerful revival and it was enlarged to double its original 
dimensions and a spacious Lecture Room added in the rear. This property we sold in 1857 for $\$ 20,000$ and the proceeds were applied towards the expense of erecting this building in which we are asgembled to-day. Thus the Lord has led us along from step to step, often through deep waters until at last we have been permitted to open the present beautiful and convenient sanctuary which we dedicated to the service of God on the last Sabbath.

[Concluded in October number.]

\section{AN ADDREGS DELIVERED BEFORE THE HAWKEYE PIONEER ASSOCIATION OF DES MOINES $r$ . COUNTY, IOWA, JUNE 2D, 1858. \\ BY HON. CHARLES MASON.}

\section{Mr. President, Ladies and Gentlemen:}

On the first day of June, 1833, the White man first set foot on the ground whereon we now stand-claiming it as his own. The former occupants, who, for centuries, had been slowly retiring before the steady progress of their more powerful neighbors, had again yielded to their destiny, and reluctantly left behind them this Great River, with the prairies and forests by which it was skirted, to follow still further the setting sun-fit symbol of the approaching extinguishment of their devoted race -and the civilized American thus obtained a foothold upon this shore, to lay the foundation of new cities, and plant the germ of another empire. We are now holding the first annual meet. ing of a Society organized to commemorate that event, so interesting, not only to ourselves, but to our country and to the whole world of mankind.

To you, Sir, and to most of those who now hear me, I can hardly offer any statement of facts which will be either novel or interesting. The event we celebrate is so recent in its date, that it seems to belong to the present rather than the past. The mists of forgetfulness have not yet obscured any of the 
Copyright of Annals of Iowa is the property of State of Iowa, by \& through the State Historical Society of Iowa and its content may not be copied or emailed to multiple sites or posted to a listserv without the copyright holder's express written permission. However, users may print, download, or email articles for individual use. 